\title{
INFLUENCE OF THE WORLD TRIAD COUNTRIES MANAGEMENT ON THE DISPROPORTIONAL DEVELOPMENT OF GLOBAL ECONOMY
}

\author{
Anatolii Vdovichen \\ Chernivtsi Trade and Economics Institute of KNTEU, Chernivtsi, Ukraine
}

\section{(C) MESTE NGO}

JEL category: F, F15, 01, 019

\begin{abstract}
Article deals with the analysis of the influence of the countries of world triad on the processes of globalization, the reasons for the balance of the proportion "investment fund - accumulation fund consumption fund" violation are studied; the imbalance of the world development and especially the uneven development of the Center and the Periphery is investigated; economic development in general and economic life of separate countries and regions modification is analyzed; the reasons of disproportions of global social and economic development are discovered; the prognostication of the development of Euro Atlantic (American), European and Asian globalism is made. Author defines several approaches concerning the reform and restructuring of the world global economic environment. Among them there are two the most dominant. The first is based on the construction of center-periphery model, which involves the federal development of a world. The second is based on liberalizing trends in monetary and financial sphere. Author indicates that formation of a complex model of regulation will become one of the main tasks of the international community (the international society) in the XXI century.
\end{abstract}

Keywords: World triad, global economy, disproportional development, globalization, economic development

\section{INTRODUCTION}

For the last 30 years management of the world economy has been characterized by some peculiarities of the development, in particular: strengthening of the social and economic

Address of the author:

Anatolii Vdovichen

莑三” danjapolina@ukr.net inequality between countries; accumulation of the considerable disproportions in the financial sphere; appearance of the essential differences in the branch structure of economic systems of different countries of the world.

During the $X X$ century the core of the world economy had been represented by the countries of the world triad (USA-Japan-EU), which, by the colossal scientific, technological and industrial potential have become the main producers of 
goods and services and, by conducting long-term aggressive expansion in all segments of the world market, they control almost $75 \%$ of international trade and approximately $80 \%$ of investments and financial flows.

In particular these countries today can really influence the quantity and quality parameters of global economic system and determine main tendencies of world economy development, while rest of the countries can only "adjust" to strategies of their corporations, activity of which have become global and oriented on setting total control over the most profitable spheres of international business and also monopoly on nature, industrial, technical, information and financial resources of receiving countries.

\section{ANALYSIS}

Among the scientific articles, which contain the fundamental development of issues, connected with the irregular character of the development of the world economy at different historical stages of its evolution, it is worth to name the works of such foreign scientists as O. Bilorus (2011) in his work "The political economy of globalization and problems of structural modernization of the national economy", V. Heyets' (2009) in his article "Macroeconomic estimation of monetary-credit and currency politics of Ukraine during and after the financial crisis", S. Korablin (2010) in his work "Postindustrial Ukraine", L. Shynkaruk (2011) in his monograph "Structural changes and economic development of Ukraine", O. Solodovnik (2010) in his article "The imbalance of the environment of the corporate sector of economy of Ukraine" and others. Their works are devoted to the research of modern processes taking place in the globalized economy, the analysis of interregional and intraregional disproportions, asymmetries, imbalances of social and economic development, trans-nationalization of economic systems and processes of a global competitive environment, economic divergence and convergence of countries, global financial integration and process of techno-globalism and so on.

But many aspects of this many-sided scientific problem, which is connected with the management of disproportional development of the world economy stay insufficiently discovered and based. In its turn it defined the aim of our research, which lies in the prism of determining the influence of world triad governments' management on the disproportional development of the global economic.

In such a way, the system research of the reasons of disproportions of global social and economic development is very important in both theoretic and practical way for the for the further development of both economy of Ukraine and European countries, which are not EU members it caused the choice of the topic of this article, its aim and tasks, which are the following: analysis of the influence of the world triad on the processes of globalization; studying of the proportions disbalance reasons "investment fund accumulation fund - consumption fund"; the prognostication of the development of Euro Atlantic (American), European and Asian globalism.

While carrying out the analysis of disproportional development of world economy, first of all, we would like to mention the analysis of the increasing influence of the countries of the world triad on the processes of globalization. In such a way American crises at the beginning of 2008, sensational collapse of the Japanese corporative economic machine since 1989, phenomenal development of China after 1978 - all these demonstrates the increase of the role of the country in the conditions of globalization.

As it is indicated in the analytical journal "Korespondent" for 2013, Japan, recently the main competitor of USA in world economic dominance, has got in trouble. Despite of the relatively successful life of ordinary Japanese, finances of the country causing the anxiety of experts, as the national debt of Japan for the moment exceeds $236,6 \%$ of GDP (GDP of Japan is 4,6 trillion USD, which is 26,2 thousand USD per head), which is the world record. To compare: for the violator of the European financial peace Greece, this index equals $175 \%$. Japanese budget deficit for the last year is approx. $10 \%$ of GDP, which also exceeds the indexes of any country from Euro zone (Korespondent, 2013, p. 37-38).

Two decades ago Tokyo used to be the main and powerful Asian tiger. It was considered that this rapidly rising economic will exceed rising economic of USA. However, the Japanese not just disappointed the expectations of experts with 
more than not reaching the scale of the leader the USA, but yielded their second place to the "new economic geeks" - China. Its export collapsed, the national debt soared, corporate culture of management became out of date, the bureaucracy increased, and the population is ageing. This is indicated by the following facts, which we will consider below.

Recently for the consumers all over the world qualitative electronics could only be Japanese, but now the initiative belongs to the USA, South Korea and China, and this in its turn affected the profits of Japanese corporations. According to the American news agency Bloomberg, the companies Sharp, Panasonic, Sony in the past five years have suffered losses of more than they could earn in the last two decades (e.g. Sharp in 2008 showed a net profit of 1 billion USD and in 2012 , the loss of the company was 4.7 billion USD). The causes of these losses - focus on equipment that uses CDs (blue-ray), expensive technology in television sets production, while in South Korea producers have begun to use more advanced and affordable technology. As a result, in 2012, Japan's trade deficit reached a record of 78 billion USD, which, in comparison with the previous year increased on 170\% (Korespondent, 2013, p. 36-37).

One more threat is the population ageing. For the last 20 years the quantity of Japanese, whose age equals or exceeds 65 years, almost doubled and reached $23 \%$. For comparison, in the USA this index equals $13 \%$ and the European average index is - $16 \%$ (Germany - $21 \%$, Italy - $21 \%$, Greece - 19\%, Sweden - 19\%). In its turn, a significant increase of the number of elderly people requires the increase of public expenses on health and social services (in Japan this article of expenditure is $29.2 \%$ of the state budget).

Japanese corporative culture also cracked, as young people don't endure heavy loads and high demands at work in large corporations, and therefore about $35 \%$ of the working of the Japanese work on a temporary basis, which as a result leads to the fact that the Japanese household income fell for more than $12 \%$ in 15 years.

The Government of Japan starts to reform pensions, public administration (debureaucratization), increases deposits (about 150 billion USD) to the modernization of enterprises and infrastructure and monetary policy conduction.

In its turn the last instrument of yen devalue can provoke monetary wars all over the world (central banks of other countries will start to devalue their own currencies to balance the appearing disproportional conditions in trade operations). It is important to understand that the action of any government (Japanese in this case) has both positive and negative effects. Thus the increasing inflation, even though it is favorable for export, it is negatively reflected on the incomes of average Japanese.

In the conditions of the globalized economy it is impossible for all the countries and especially for Ukraine, or any other country of Europe to overcome the disproportions in the development of country economy without cardinal, unpopular extensive structural and modernizing reformative administrative actions.

In its turn, a high propensity to investments and low personal consumption in countries with emerging markets increased their immunity to the crisis phenomenon in the global economy. Thus, investments in China increased from $30-35 \%$ of GDP in 1990th to $45-50 \%$ in the current decade, and the part of private consumption remains extremely low (Korablin, 2010)).

At that diversified investments in technology and production inputs made this country almost immune to the crisis: after the slowdown of China's GDP to $6.1 \%$ in the mid-2009, six months after they again rose to $9 \%$.

According to the data, provided by the scientific and analytical journal "Korrespondent" for 2013 China had set a record by the scale of trade turnover, leaving behind the permanent leader on this index, USA, who had been the leader since 1950. In 2012 China sold goods for 3.87 trillion, which equals more than half of its GDP, and USA - for 3.82 trillion USD. Its growth was reached owing to the increase of the internal consumption, and it in its turn changes the alignment of forces in the world globalized business-arena. For example, Germany, the economic leader of EU, considers China as one of the priority trade partners. By the year 2020 the import from Germany to China would have be exceeded, 
according to the data of the invest bank Goldman Sachs analytics, the supply of the German goods to the neighboring France. Now the financiers aspire to foreseen when China will put an end to the competition with USA, showing the biggest GDP in the world. According to the estimation of the international audit company PricewaterhouseCoopers, this is going to happen in the nearest four years, and only force majeure obstacles of the third world war scale can prevent it (Korespondent, 2013, p. 8).

During the period 1950-2005 the share of China in the world GDP rose from 3.3 to $20 \%$. It is expected that in 2025 it will first surpass the United States by GDP (China's GDP is 20 trillion dollars, and the USA is 14-15 trillion dollars) and will take the second place by the scale of the total national wealth. In 2006 China spent 60 billion USD on research and scientific development and in 2025 it will invest in this sphere more than 100 billion USD. Today it invests into the economy phenomenal savings - $45 \%$ of GDP. Since 1978 a lot of countries have invested to China. In 1978 to China was invested 500 billion USD. As a result of industry growth has reached on the average $18 \%$ per year. China sees itself as a potential superpower of the world. By 2050, it would really become such a new superpower. Its policy will be active expansion.

In recent years, the list of China's economic victories increased, and already for four years it has been a leading exporter and the world's largest car market. The country is also considered to be the record-holder of the electricity consumption. Besides, China is the main producer of gold in the world and the largest holder of foreign reserves -3.3 trillion USD.

So, taking into consideration that the correlation between accumulation and consumption significantly influence the rates of production increase, the level of population consumption and effectiveness of social reproduction, we can conclude that breach of proportions balance "investment fund - accumulation fund consumption fund" in favor of personal consumption in the developed countries has become the factor which limited their possibilities in provision of the further stable economic development and increase of the investment scope under the limited personal consumption in the countries with markets which are being formed, have strengthen their unreceptiveness to the manifestation of the global crisis (Solodovnik, 2010, p.77).

We think that the backgrounds of the crisis worth to be sought in the proportions which characterize the formed in the last dozen of years structure of money and correlation of full-bodied money and not full-bodied money (quasi-money).

Private capital always sensitively reacts on the threats of the economic and political stability and when such threats really appear, it chooses various foreign investments as the means to preserve itself. Outflow of capital determines the wastes of not only separate country, but it is also the factor which destabilizes the financial systems of other countries. Particularly the flow of the "hot money" can have inflationary consequences, lead to increase of rate and credit risks in the country, to which they are directed and become a reason of balance and economic stability disturbance of the world (example: Ukraine).

One of the directions of the economies of the former Soviet bloc market transformation in the 1990s of the twentieth century was the accelerated liberalization of the monetary and financial relations, which in terms of infrastructure underdevelopment of financial markets and the lack of necessary legislation has created favorable conditions for illegal withdrawal of significant amounts of capital to developed countries. Local financial crises that occurred during this period in Asia and Latin America, has also been accompanied by the influx of "hot money" on the financial markets of developed countries. Therefore, even before the global financial crisis, the volume of "hot money" and short-term capital, which have a high degree of mobility and are practically not implemented in the real economy, at times exceeded financial strength of the central banks and national governments. The growth of the financial and political risks in countries with emerging markets, also resulted in the change of direction of direct investment of the developed countries, the priority recipient of which is the corporate sector in other developed countries (Solodovnik, 2010, p.77).

There is a thought that by the year 2025 the Asian globalism as a system would have become stronger than Euro-Atlantic globalism and would 
totally dominate in "non-western" part of the world. Global Americanization would face more and more strong opposition. On this base European globalism of European Union would become relatively stronger. Union of powers of EuroAtlantic (American), Asian and European globalism would contribute to general strengthening of the globalism system and its transformation into the new social and political formation. The process of globalization would become unceasing and its consequences (positive and negative) would become unalterable.

According to this scenario globalization will lead to the world-wide consolidation already in 2015-2080 to the level, which foresees forced coercive globalization with creation of global supra-state bodies under the control of vanguard "global" countries, and USA would pretend to this position most of all. Let us notice, that USA requires "freedom of global market space" but at the same time they don't hurry to globalize and rank one of the last places in the world by the level of global dependence and globalization of their economy with the index of only $10-12 \%$ (Bilorus, 2011,pp.7$10)$.

Strengthening of economic globalization in their opinion of "those who globalize" will inevitably lead to political globalization which will for sure cause creation of the "world government", the aim of which will be the "building of the new global world structure", i.e. global state for those who globalize, correspondingly with their manager. Not in vain European theorists of anti-globalism stand against coercive globalization and consider that exactly national strategies and politics and not the "invisible hand of the global market" would determine the economic development of the world.

Most of the contemporary scholars consider that the power globalism is purely USA project. Even the American scholars-economists and businessmen recognize it as the "fundamentalism of the free global market". With the help of the globalization USA try to conduct "revolution capture" of the whole world economy. Any other economic civilization, besides the globalism system, is being reclined by them. Only 10 developing countries managed to integrate into the globalized market of the 20th century. Among them there is neither Russia, nor Ukraine or other countries of the Eastern Europe. We should think of it. Let us give such examples of the globalization results: $81 \%$ of the direct investments capitals fall on northern countries of the life level - USA, Britain, Germany, and Canada. And if the developing country stops guarantying superprofits to the global investment capital, in such a case, its escape from there can be provided with a single click of the computer.

Theory of global studies and future political economy of globalism, as a new social and political order must disaffiliate with necessity of uniting the existing power of TNC with first-priority power of national countries which can be united in different unions.

O. Belarus in his research indicates that the authorities of Ukraine should understand that the future of the country lies primarily in the way of their competitive technological and managerial integration to strong global institutions such as the European Union. So first of all it is necessary to solve the problem of international competitiveness of Ukraine's economy and its public and corporate management. We also should remember that in the twenty-first century the legitimacy of any economic system will be measured by the level and quality of life of working citizens and not billions of dollars of the batch of oligarchs. We believe that Ukraine will be able to effectively join the future integration of the global system that is created around the EU. This is the particular objective interest of such leading European countries as Britain, France, Germany and Italy where the unemployment rate has reached 10$12 \%$. Without Ukraine, the political and economic system of Europe is not globally competitive. Especially if to take into consideration the fact that the danger of malignant globalization model for the USA are not limited with only economic threats. Against the backdrop of population growth in the USA, in the West, taken as a whole, there is the extinction of countries - there are raging demographic crisis and the process of depopulation. Today the non-Western world is 5 times larger than the West, and in 2050 it would be 10 times larger. The population of the West is reducing not only by relative but also by absolute terms. Thus the West is aging, and the East is getting younger. Western Europe has no reserves, as the population of Russia and Ukraine is also reducing. In 2000, the population of Great Europe, 
including Eastern, was 728 million; in 2050 it will decrease to 556 million, i.e. on 172 million people. And according to the forecasts in Russia by 2050 beyond the Urals will stay less than 1 million of ethnic Russians (Bilorus, 2011, pp.13 -14).

Imperial globalism of both USA and Asia will lead to explosive inequality. Even now the ratio between the standard of living of the $20 \%$ rich and the $20 \%$ of poor in the world is $1: 75$. The critical level may be 1:100, which will inevitably lead to the global social explosion. This is not a science fiction, this is social globalization. As we have already noted in 2050 China's GDP will exceed USA GDP in $75-80 \%$. Center of political and economic power will move to Asia. In 2025 Asia will produce $45-50 \%$ of world GDP. Asian economic leadership is inevitable. Forecasts show that by 2050 the share of Asia, led by Tianxia in the global economy will reach $57-60 \%$. But how would the Asian globalism look like?

In the West, European Union together with USA can resist China but on conditions that EU would successfully realize global strategies which it already has. European Union is now practically equals a world hegemon, i.e. USA, in trade and currency spheres. Global strategy of EU consists in transformation of monopolar world of USA into more difficult and more acceptable structure. European Union also has to displace itself in the sphere of economics and global safety. But global strategy of European Union significantly differs from American, as it doesn't require the hegemony over the world for itself. Europe doesn't consider itself the Center of the world. It wants to be the center of people's development and progress.

So, the process of globalization had become the logical continuation of world economy upheavals which happened at the edge of the centuries and have been characterized, first of all by the changes in the world economy system. At the edge of the millennium economic development in general and economic life of separate countries and regions modified significantly, indicating the influence of new factors - appearance of new industrial, transport and communication technologies, unseen before forms of organization and management (enlarged international corporations) with the simultaneous sharpening of the competitiveness. The integrated global market as the integrity of planetary scale has appeared.
The process of globalization has significantly intensified the rates of innovations and demonstrated the necessity of creation of flexible markets of labor, goods, capital, modification of the existing principals of regulation and management. Functions concerning national regulation of their economics got out of control. Hard and global competitiveness undermines the effectiveness of models of social orientation, the problem of finding a "free niche" in the new international division of labor becomes sharper. Such changes cause significant effect on the financial sphere, where mass and fast international overflows of loan capitals distorted the balance in this sphere and provoke various crisis situations. As a rule, serious financial problems in a particular national economics rather quickly transfer to ("infect") other countries (Argentina default). Powerful bank or monetary disasters are spread around the world with unprecedented speed (striking example of this is Asian crisis of 1997-1998, and 1998-1999 Russian crisis) The current financial crisis of 2008 , which began in the United States with the bankruptcy of mortgage banks also turned into world crises instantly.

\section{CONCLUSIONS}

The imbalance of the world development and especially the uneven development of the Center and the Periphery were expressed in the most sensitive sphere - the sphere of credits and finances. Rapid globalization of world economic processes, which originated from the late 70's and early 80 's of the $X X$ century was accompanied by a number of acute financial turmoil. In the conditions of the increasing openness of the economies this kind of turmoil and crisis cause damages to even those countries that are not directly involved in this process. Violation of the entire system of economic relations became the natural result of strengthening such imbalances in the world economy development, as: asynchrony of the development and increasing gap between financial sphere and the real sector of economy, the instability of the ratio between accumulation and consumption, a growing imbalance between the amount of savings and investments, change of the direction and structure of cross-border flows of capital, continued imbalance in the current accounts and capital transactions. 
That is why world community sharply faces the problem of improving the mechanisms and methods of collective regulation of global processes - search for fundamentally new, supranational regulatory model of global economic processes. As of today, there are several approaches concerning the reform and restructuring of the world global economic environment. Among them there are two the most dominant. The first is based on the construction of center-periphery model, which involves the federal development of a world. The second is based on liberalizing trends in monetary and financial sphere. Formation of a complex model of regulation will become one of the main tasks of the international community (the international society) in the XXI century (Vdovichen, 2012).

So that Ukraine was able to use the opportunities of the present crisis to strengthen its position in the global economic and political space it is necessary to conduct scaled restructuring of corporate sector, which should be based on a combination of innovative activities of corporations with a common industrial policy of the state on the basis of objectivity of correction value of assets in global and domestic markets, limitation of the foreign direct investment, the growth of mobility and unpredictability of traffic. This requires the complex methodological studies of mechanisms of formation and portfolio investment flows, largescale violations of international trade balance, as well as prediction of ways of rapprochement of financial and real sectors of the economy, the implementation of programs of macro and micro restructuring of the domestic corporate sector in the crisis and post-crisis development of the world economy.

\section{WORKS CITED}

Bilorus O. (2011) Politychna ekonomiya hlobalizmu i problemy strukturnoyi modernizatsiyi natsional'noyi ekonomiky / The political economy of globalization and problems of structural modernization of the national economy, Doslidzhennya mizhnarodnoyi ekonomiky: Zbirnyk naukovykh prats', ed 2 (67), pp.3-26.

Heyets' V. (2009) Makroekonomichna otsinka hroshovo-kredytnoyi ta valyutno-kursovoyi polityky Ukrayiny do i pid chas finansovoyi kryzy/ Macroeconomic estimation of monetary-credit and currency politics of Ukraine during and after the financial crisis // Ekonomika Ukrayiny, №2, P. 5-23.

Korablin S. (2010) Ukrayina postindustrial'na/ Postindustrial Ukraine // Dzerkalo tyzhnya, N 4(784). - P. 7.

Korespondent (2013), №6 (545): www.correspondent.net

Shynkaruk L. (2011) Strukturni zminy ta ekonomichnyy rozvytok Ukrayiny: monohrafiya/ Structural changes and economic development of Ukraine: monograph, NAN Ukrayiny, Kiev, 696p.

Solodovnik O.O. (2010) Dysproportsiyi rozvytku zovnishn'oho seredovyshcha korporatyvnoho sektoru ekonomiky Ukrayiny / The imbalance of the environment of the corporate sector of economy of Ukraine, Aktual'ni problemy ekonomiky, №7 (109), pp. 73-80

Vdovichen A.A. (2012) Osoblyvosti dysproportsiynosti natsional'noyi ekonomiky u konteksti mizhnarodnykh porivnyan'/Peculiarities of disproportion of national economi in the context of international comparisons//Visnyk Chernivets'koho torhovel'no-ekonomichnoho instytutu, Chernivtsi:ChTEI KNTEU, Ed.I(45), Ekonomichni nauky, P. 47-60.

Received for publication:

Revision received:

Accepted for publication:
31.01 .2014

13.06.2014

07.07.2014 


\section{How to cite this article?}

Style - APA Sixth Edition

Vdovichen, A. (2014, 07 15). Influence of the world triad countries management on the disproportional development of global economy. (Z. Čekerevac, Ed.) MEST Journal, 2(2), 266273. doi:10.12709/mest.02.02.02.27

Style - Chicago Fifteenth Edition:

Vdovichen, Anatolii. 2014. "Influence of the world triad countries management on the disproportional development of global economy." Edited by Zoran Čekerevac. MEST Journal (MESTE) 2 (2): 266-273. doi:10.12709/mest.02.02.02.27.

Style-GOST Name Sort:

Vdovichen Anatolii Influence of the world triad countries management on the disproportional development of global economy [Journal] // MEST Journal / ed. Čekerevac Zoran. - Belgrade : MESTE, 07 15, 2014. - 2 : Vol. 2. - pp. 266-273.

Style - Harvard Anglia:

Vdovichen, A., 2014. Influence of the world triad countries management on the disproportional development of global economy. MEST Journal, 15 07, 2(2), pp. 266-273.

Style - ISO 690 Numerical Reference:

Influence of the world triad countries management on the disproportional development of global economy. Vdovichen, Anatolii. [ed.] Zoran Čekerevac. 2, Belgrade : MESTE, 07 15, 2014, MEST Journal, Vol. 2, pp. 266-273. 